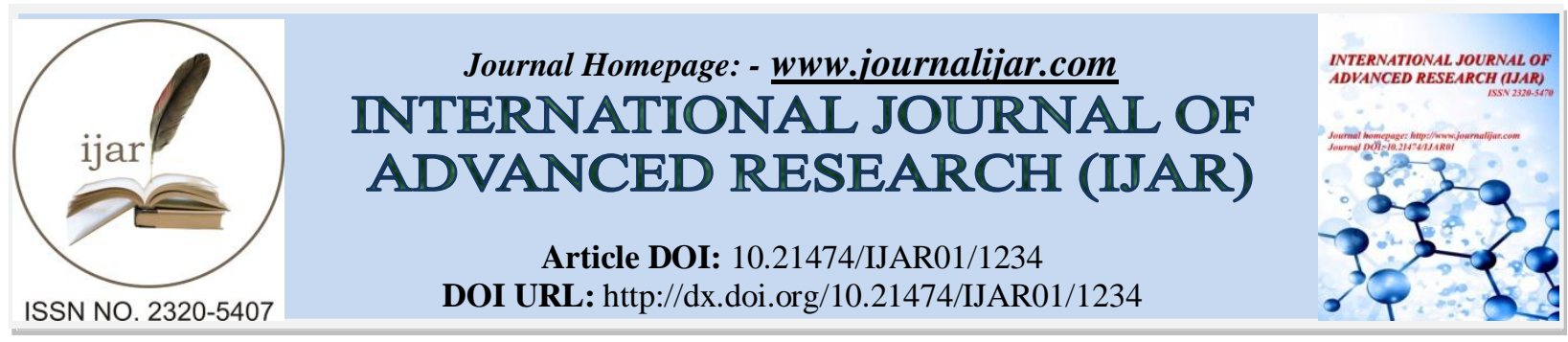

RESEARCH ARTICLE

\title{
EFFECT OF FINANCIAL CAPABILITY ON INVESTMENT AMONG FINANCIALLY INCLUDED YOUTH: CASE OF NYERI AND KIRINYAGA COUNTIES, KENYA.
}

\author{
*Richard M Kiai ${ }^{1}$, S. I. Ng'ang'a. PhD ${ }^{1}$, David N Kiragu. PhD $^{2}$ and Josphat K Kinyanjui. PhD ${ }^{1}$. \\ 1. Karatina University, Kenya. \\ 2. Dedan Kimathi University of Technology, Kenya.
}

\section{Manuscript Info}

Manuscript History

Received: 18 June 2016

Final Accepted: 26 July 2016

Published: August 2016

Key words:-

Financial inclusion, investment,

financial concepts, financial

management skills, financial discipline.

\begin{abstract}
Financial inclusion has been found to play a critical role in poverty and unemployment reduction through household investments. This has seen countries put concerted efforts towards enhancing financial inclusion with the main objective of reducing poverty and unemployment. Kenya has also put efforts and has seen notable levels of increase of financial inclusion. Majority of the citizens can now access wide range of financial services. Contrary to high levels of financial inclusion in Kenya, unemployment and poverty levels are still high in Kenya and more pronounced among the youth. The purpose of this study was to establish whether financial capability has any effects on investment among financial included youth in Kenya. Specifically, the study was to establish whether financial products awareness, financial concepts understanding, financial management skills and financial discipline affects investment among financially included youths in Kenya. The study population was Kenyan youth aged between 18 to 35 years from Kirinyaga and Nyeri Counties. A logistic regression analysis was conducted to predict undertaking investments using financial products awareness, financial concepts understanding, financial management skills and financial discipline as predictors. The Wald criterion demonstrated that financial concepts understanding, financial management skills and financial discipline made a significant contribution to prediction. Financial products awareness was not a significant predictor. As a way of enhancing investment and ensuring financial inclusion achieves its objective, this study recommends enhancement of financial capability among the youth.
\end{abstract}

Copy Right, IJAR, 2016,. All rights reserved.

\section{Introduction:-}

Financial inclusion is the provision of affordable financial services, which includes access to payments and remittance facilities, loans, savings and insurance services by the formal financial system to sections of disadvantaged and low-income segments of society (Hannig and Jansen 2011). Globally, financial inclusion has been broadly recognized as critical factor in reducing poverty and achieving inclusive growth through household investments (Demirguc-Kunt, Klapper, Singer and Oudheusden, 2015). This has seen world economies taking 
financial inclusion as a global agenda and countries have been advocating for increasing financial inclusion among its citizens (Centre for Financial Inclusion, 2014). Organizations both international and local have set aside huge amount of resources towards improving financial inclusion in the various countries across the world (FinAccess, 2009). World Bank is an example of an organisation that has put a lot of advocacy and set aside huge amounts of funds in trying to help economies improve financial inclusions (World Bank, 2014). The bank has also been undertaking a lot of research on the various facets of financial inclusion.

The focus of financial inclusion in Africa has also been taken with similar interest. Studies had indicated that more than 90 per cent of the population was excluded from access to the formal financial system over the last 10 years (United Nations, 2006). Due focus on financial inclusion, the scenario is changing with time and Africa has made significant achievement towards enhancing financial inclusion (Demirguc-Kunt et al., 2015). The average financial inclusion for Africa as per the Global Findex Database 2014 stood at 34\% from 24\% in 2012 (Demirguc-Kunt et al., 2015; Demirguç-Kunt and Klapper, 2012).

Kenya has equally carried this global agenda with zeal. The lead in this is the Central Bank of Kenya where a number of reforms in the banking sector since 2007 have been largely geared towards enhancing financial inclusion (CBK, 2015). Kenya government does not only advocate for financial inclusion at policy level. It has also set funds for vulnerable groups, women and the youth which include women fund, youth fund and Uwezo fund (RoK, 2013a). With the regulatory reforms, financial institutions are able to use advances in technology including mobile telephones, handheld devices, and point-of-sale devices, low-cost ATMs and kiosks (Kalunda, 2012). Due to these efforts, Kenya has achieved great levels in mobile money and other forms of electronic money.

On overall, Kenya has achieved high levels of financial inclusion. Villasenor, West and Lewis (2015) noted that 76\% of the Kenyans were financially included. Another study by World Bank (2014) indicated that financial inclusion in Kenya was $75 \%$ which compared favorably to the global average which was $44 \%$. Again, FinAccess (2013) noted that at least $65 \%$ of the Kenyan population was using digital financial services. The latest study was in 2016 where it was indicated that $75.3 \%$ of Kenyan adults are now included (FinAcess, 2016).

The much advocacy on Financial Inclusion is due to the fact that financial inclusion is critical in reducing poverty and achieving inclusive growth through household investment (Demirguc-Kunt et al., 2015). It has been the wish of the government that all citizens have a source of income. Study by a number of researchers has confirmed that financial inclusion has been instrumental in reducing poverty and unemployment through household investment (Ashraf, Karlan \& Yin, 2010; Ellis, Lemma \& Rud, 2010; Mastroyiannis, 2007; UNDP, 2013; World Bank, 2008). These studies provide a strong association between financial inclusion, poverty reduction and employment creation through household investment (Narayan, 2005; UNDP, 2013)

The financial inclusion in Kenya seems not to play the critical role of inclusive economic growth. Despite the increase in financial inclusion in Kenya, the unemployment and poverty levels are still high and more pronounced among the youth. The poor have not been able to invest and move out of poverty (Balwanz , 2012; KNBS, 2014; Rok, 2013b). Those who are financially included have increased from $26.4 \%$ in 2006 to $66.7 \%$ in 2013 (FinAccess, 2013),75\% in 2015 (Demirguc-Kunt et al, 2015) and 75.5\% in 2016 (FinAcess, 2016), while those living below the poverty line have moved to about $42 \%$ from about $47 \%$ in the same period (World Bank, 2014). The rate of unemployed youth increased from 12.5\% in 2006 to about 25\% in 2013 (Mutia, 2014). Other studies indicate that Kenya compares poorly in reducing unemployment among other low income countries (Mutia, 2014; RoK, 2013b; World Bank, 2014). The purpose of this study was to find out whether financial capability has any influence on investment among financially included youth.

\section{Problem statement:-}

The benefits of financial inclusion have been recognized world over. It has been confirmed that financial inclusion plays a critical role in household investment. This leads into unemployment and poverty reduction (United Nations, 2015; Ashraf et al., 2010; UNDP, 2013; World Bank, 2008). Many countries have been advocating for increasing financial inclusion among its citizens due to this critical role (Centre for Financial Inclusion, 2014). Kenya has equally worked hard in improving financial inclusion levels. This has been in policy formulation that has been facilitated by Central Bank of Kenya and other institutions like Kenya Financial Sector Deepening (FSD) (FinAccess 2006; Kimani 2013) and provision of funds (RoK, 2013a). Despite the high increase in financial 
inclusion, household investments are still low among the youth. The levels of unemployment and poverty are still high among the youth. It has also been noted that financial capability among Kenyans is low and especially among the youth (Githui and Ngare, 2014). The purpose of this study was to establish the influence of financial capability on investment among financially included youths in Kenya.

\section{Objective of the study:-}

Establish the effects of financial capability on investment among financially included youth in Kenya.

\section{Theoretical and literature review:-}

Access and inequality theory holds that access to finances determines how different household will be able to develop themselves economically and the income inequality in an economy is reduced (Piketty, 1997). The level of access to finance determines the extent to which talented but poor individuals can raise external funds to initiate projects. Banerjee and Newman (1993) indicated that individuals' current occupational choices are limited by their initial endowments. The structure of occupational choices of whether people can move to higher income level or have to remain wage earners in turn determines how much they can save and what risks they can bear with long-run implications for growth and income distribution. Thus, if household does not have access to finances, then he it will remain in poverty and income inequality (Banerjee and Newman, 1993; Galor and Zeira, 1993).

In support of the Pikketty's theory on finance and inequality, Evans and Jovanovic (1989) argued that lack of access to finance limits the opportunities of the poor and affects the intergenerational returns on investment. They further argued that, investment opportunities are actually a function of household's access to financial assets. When a household investment opportunity is constrained by the ability to access finance, it creates a situation of persistent inequality. Investments requirements with a high return are associated with high cost of capital and they are limited to the wealthier people. The financial market imperfections affect the degree to which the level of asset influences the returns that are available to household and they affect the poor people more.

Imperfect credit theory holds that, where the credit markets are imperfect, those with no initial wealth face a limited investment opportunity and as they are not able to get funds to invest on the available opportunities (Piketty, 1997). This leaves those who are poor to remain poor. The credit constraints make the wealth creation to be limited to those households with wealth or who come from wealth families. Loury (1981) in support of imperfect credit theory argued that the source of credit constraints are related to initial wealth. The consequence of the credit constraints is that unequal wealth may prevent some profitable investment from being undertaken. By allowing larger number of children and household to educate and invest, wealth redistribution can reduce inequality, raise the intergenerational mobility of earnings and increase output at the same time.

Newman (1991) agreed with imperfect credit theory and indicated that credit constraints and value of the initial wealth also imply the occupational choice. The implication of this is that the poor are constrained by poverty traps (Banerjee and Newman, 1993). Those who are poor remain poor forever and those who are wealth accumulate more wealth, the initial wealth inequality continues for ever. However, in the economies where first-best credit, where initial wealth is irrelevant from the view point of productive efficiency, initial wealth should not have any consequence on distribution of earnings and wealth (Piketty, 1997).

With financial inclusion, access to financial in not limited to those with initial wealth. Again, credit is not limited to people with initial wealth, rather to first-best credit policy where viability of the investment is considered. Thus, with increase of financial inclusion, the poor are also expected to take advantage of financial services and undertake investments. Access to financial services and having financial capability to take advantage of the same has been confirmed to have positive effects on investment. Access and usage of credit has been indicated to help investments in assets that enable individuals to start or grow their businesses (Cull, Ehrbeck and Holle, 2014). Augsburg, de Haas, Harmgart, and Meghir (2012) noted that there is evidence that credit both spurred new business creation and benefitted existing micro businesses in Mongolia and Bosnia. World Bank (2014) found positive effects from access to credit on a variety of indicators, including the income of existing businesses in India and Mongolia, business size in Mexico, and the scale of agricultural activities and the diversification of livestock (Morocco). This clearly indicates that providing saving and credit facilities can enhance investment among the youth (Cull et al., 2014). 
A number of studies have been done on financial capability. To start with, in the study of financial capability and financial inclusion, Ibrahim and Alqaydi (2012) carried out a study to examine financial capability among a sample of individuals living in the United Arab Emirates (UAE) and its relation to different forms of financial products. The study noted that the level of financial capability was low. On the relationship, the results of the study indicated that the average level of financial in UAE was statistically significantly in usage of financial products. The study concluded that the level of financial capability affected the usage of the financial products.

The usage of financial services is hindered by the level of financial capability. Ellis et al., (2010) studied the impact of financial capability on financial inclusion using FinScope survey data from Kenya and Tanzania. Specifically, the study was examining saving and borrowing behavior by individuals, the reasons for which they invest, the barriers to access they face, the types of financial services they use, and how this varies according to individual characteristics. The main supply side barriers to access identified by survey respondents in both countries related to lack of financial capability, that is, not knowing where to access a financial service, or how financial services work. The study concluded that due to the low level of financial capability, the people were not able to take advantage of financial inclusion.

Githui and Ngare (2014) confirmed that financial capability influences significantly on financial decision making. The data of the study was primary that was collected by use of a questionnaire and face-to-face interviews and was analyzed both in descriptive statistics and in inferential statistics. The study noted that Kenya is a country with a relatively young and rapidly growing population with relatively low levels of financial capability and low per capita incomes. The study concluded that, the low levels of financial capability negatively affect financial decisionmaking.

Agarwal, Driscoll, Gabaix and Laibson (2009), from a study of about 128,000 credit card holders found that 28 percent make mistakes and they pay extra penalties. Ellis et al., (2009) noted lack of financial capability was impending the usage of financial services by Kenyans towards usage of financial products. CYFI (2012) indicated that with increase in financial literacy can lead to increased financial management and usage of financial products, which leads to increased investment and improved economic growth.

It has been indicated that, low levels of financially capability affects future financial decision-making. Lusardi and Mitchell (2011) show that those who display low financial literacy are less likely to plan for retirement and as a result accumulate much less wealth. Thus, individuals are not able to take advantage of financial inclusion when financial capability is low. Financial service providers exploit the low level of financial capability and sometimes individuals pay higher interest rates than they should. Other studies that have indicated similar trend when the same test scores are used (Lusardi and Mitchell, 2011).

\section{Research methodology:-}

This study adopted positivism philosophy. On research design, this study adopted a descriptive survey research design while probabilistic sampling design was used for this study to sample the respondents. The main data for this study was primary data that was collected between December 2015 and February 2016 using a questionnaire. To confirm reliability, Cronbach's alpha coefficient was computed which was 0.845 and it was considered appropriate.

\section{Data Analysis, Presentation and Interpretation:- Response rate and respondents characteristics:-}

Four hundred and sixty seven (467) questionnaires were distributed of which four hundred and twenty (420) questionnaires were accurately filled and used for analysis representing $89.9 \%$ response rate. The respondents were $52.9 \%$ male while female were $47.1 \%$. As regards to age, 18-20 years, was $13 \%, 21$ to 25 years was $32 \%$, age group 26 to 30 years was $25 \%$ while age group 31 to 35 years was $30 \%$. Majority of the respondents, $55.4 \%$ were not married while $44.6 \%$ were married. On status of place of residence, majority of the respondents, $74 \%$ were rural dwellers while $26 \%$ were urban dwellers. On education, $7.6 \%$ didn't have formal education, while the total of youth whose education was beyond secondary school was 69.8 percent.

On economic indicators, the study noted that the youth who were not working were 24.5 percent. Those who were casual laborers were 25.7 percent while 6.7 percent were working in the family business, while 29.3 percent were self employed. Only 13.1 percent were formally employed. On income levels, 18.7 percent were found not to be 
earning anything whereas majority 30.1 percent were earning less than Kshs 5,000 (49 US Dollars). The average income per month was Kshs 9,089 (89 US Dollars) which translated to about Kshs 303 (3 US dollars) per day. The results indicated a poor state of the youth in terms of economic status.

The study found that, the level of financial inclusion in terms of access to financial services through bank accounts was $77.8 \%$ while mobile money account was at $81 \%$. The 77.8 percent of bank account and 81 percent ownership of mobile money account clearly indicated high levels of financial inclusion among the youth. The study also evaluated the level of investment among the youth where only $47.3 \%$ had undertaken investment. The study also noted that, majority of the youth financed their investments from own savings at 26.9 percent of the total population, followed by loans at 16.7 percent of the total population. Out of 16.7 percent, only 11.9 percent had borrowed from formal financial institutions. Insurance uptake was also low at 17 percent only. The results showed apathy in maximum utilization of financial services. Though majority of the youths were not earning or earning very little, only less than half had undertaken some form of investment. This is against the fact that majority had access to financial services.

\section{Descriptive statistics of financial capability:-}

To evaluate financial capability, four variables were considered. These included financial products awareness, financial concepts understanding, financial management skills and financial discipline. On financial products awareness, the average score was 0.9317 out of 1 , with the overall standard deviation of 0.0527 . Further analysis indicated that $70.5 \%$ were aware of all the financial products indicating high levels of awareness. On financial concepts understanding, the study required to the respondent to indicate understanding of computation interest rate, risk diversification, inflation and simple arithmetic. The study noted that only $24.7 \%$ had an understanding of all the four concepts.

Financial Discipline and Financial Management Skills were measured through self-evaluation where likert scale was used. The study noted that, out of 5 possible score, the mean score for the parameters was 2.47 which is less than half and positively skewed indicating low levels of financial capability as per the two variables. The data for financial management skills and financial discipline had eight parameters. Principal component analysis, which is a variable reduction procedure, was used to reduce to two factors. Kaiser criteria of Eigen value $>1$ rule was used to determine the data to retain where component that displayed an Eigen value greater than 1.00 was retained as it was accounting for a greater amount of variance that had been contributed by one variable.

\section{Relationship between Financial capability and investment among the youth in Kenya:-}

In testing the hypothesis, binary logistic regression equation model was used in the form of $\operatorname{Logit}[p]=\ln \left[\frac{p}{1-p}\right]=\beta_{0}+\beta_{1} X_{1}+\beta_{2} X_{2}+\beta_{3} X_{3}+\beta_{4} X_{4}$. The variables of the study were $X_{1}=$

Financial Concepts Understanding, $\mathrm{X}_{2}=$ Financial Products Awareness, $\mathrm{X}_{3}=$ Financial Discipline and $\mathrm{X}_{4}=$ Financial Management Skills. To compute the probability of the overall significance statistics, the following formula was used;

$$
p=\frac{e^{\beta_{0}+\beta_{1} X_{1}+\beta_{2} X_{2}+\beta_{3} X_{3}+\beta_{4} X_{4}}}{1+e^{\beta_{0}+\beta_{1} X_{1}+\beta_{2} X_{2}+\beta_{3} X_{3}+\beta_{4} X_{4}}}, \text { n }=4
$$

Where:

$\mathrm{p}=$ the probability that youth will invest,

$\mathrm{e}=$ the base of natural logarithms (approximately 2.72 ),

A test of the full model against a constant only model was statistically significant, indicating that the predictors as a set reliably distinguished between those who invested and those who did not invest (chi square $=26.090, \mathrm{p}=.000$ with $\mathrm{df}=4$ ). The strength of relationship between predictor variable and responsive variable was tested by use of the likelihood and pseudo- $\mathrm{R}^{2}$ values. The results of the study indicated that -2 Log likelihood was $549.445^{\mathrm{a}}$, Cox and Snell R Square was 0.061 and Nagelkerke R Square was 0.081. Nagelkerke R Square indicated that $8.1 \%$ of the variation was determined by the variables of the study. 
Hosmer and Lemeshow Test, was used to tests whether he model was a good fitting model. The results of the test indicated a chi-square of 11.254, with 8 degrees of freedom and p value of 0.188 . The H-L statistic has a value of 0.188 which means that the model of the study is quite a good fit. This was further confirmed by prediction success overall which improved from 52.6 percent to 64.5 percent.

The Wald criterion demonstrated that Financial Management Skills, Financial Discipline, and Financial Concepts were statistically significant, but Financial Product Awareness though positively related to investment was not statistically significant.

Table 1:- Binary Logistic Regression of Financial Capability and Investment

\begin{tabular}{|l|l|l|l|l|l|l|l|}
\hline \multicolumn{2}{|l|}{} & B & S.E. & Wald & Df & Sig. & Exp(B) \\
\hline Step $1^{\text {a }}$ & Financial Concepts & .284 & .113 & 6.297 & 1 & .012 & 1.328 \\
\cline { 2 - 8 } & $\begin{array}{l}\text { Financial Products } \\
\text { Awareness }\end{array}$ & .041 & .071 & .338 & 1 & .561 & 1.042 \\
\cline { 2 - 8 } & Financial Discipline & .217 & .106 & 4.237 & 1 & .040 & 1.243 \\
\cline { 2 - 9 } & $\begin{array}{l}\text { Financial Management } \\
\text { Skills }\end{array}$ & .264 & .105 & 6.302 & 1 & .012 & 1.302 \\
\cline { 2 - 8 } & Constant & -1.367 & .784 & 3.035 & 1 & .081 & .255 \\
\hline
\end{tabular}

a. Variable(s) entered on step 1: Financial Concepts, Financial Products Awareness, Financial Discipline, Financial Management Skills

The model the study was;

Logit of $($ Invest $)=-1.367+(0.264) *$ Financial Management Skills $+(0.217) *$ Financial Discipline $+(0.041) *$ Financial Products Awareness + (0.284)* Financial Concepts. The positive b coefficients for predictor variables indicated that increasing predictor variables score is associated with increased odds of investing. The Odds ratio expressed as $\operatorname{Exp}(B)$ column indicate the overall effect on dependent variable of increasing the predictor variables.

\section{Discussion of Findings, Conclusion and Recommendation:-}

The levels of financial inclusion revealed by this study were high and in they were agreement with other studies on the level of financial inclusion. A study in 2015 indicated that $76 \%$ of the Kenyans were financially included (Villasenor et al, 2015). World Bank (2014) also carried a study on financial inclusion globally and noted that financial inclusion in Kenya was $75 \%$ which compared favorably to the global average which was $44 \%$. Again, FinAccess (2013) noted that at least $65 \%$ of the Kenyan population was using digital financial services. InterMedia survey (2014) also found that about 74 percent of Kenyans surveyed in September 2014 had access to a bank, mobile money services, or both. FinAccess (2016) has indicated that $75.3 \%$ of Kenyan adults are now included. Thus the results of this study fully agrees with other studies on financial inclusion in Kenya and especially FinAccess (2016) study whose data was collected almost at the same period with this study.

This study has also indicated that, financial capability was low among the youth. This study was thus interested in testing whether financial capability could be affecting investment among financially included youth. Financial capability helps individuals to use financial services to their advantage. Results of this study indicating low levels of financial capability mean that, the youth may not be in a position to take full advantage of financial inclusion for their own economic benefit. World Bank (2008) noted that financial capability helps people make good decisions from the expanding financial services. Thus with higher levels of financial capability, the individuals will be making useful financial decisions. Individuals are able to take advantage of financial services and undertake economic activities when they are provided with financial services (World Bank, 2014).

This study noted though the youth were financially included, the usage of credit facilities and insurance was low. Cole, Sampson, and Zia (2011) noted that the more the person has financial capability, the more the person was to use financial products. The findings further noted that financial capability intervention had a bigger impact on people without education and for those who started with lower levels of financial literacy. Mbarire and Ali (2014) in a study on determinants of financial literacy in KPA employees noted that the level of financial capability was low among the employees. The study was form the fact that, there were many financial products in the market and the employees were not able to make sound financial decisions. The youth in this study were also found not to use fully the financial products in the market. 
Usage of credit has actually been found as a catalysts towards investments, however only $11.9 \%$ were found to have borrowed for investment purposes in this study. This was not unique to this study. Mwangi and Sichei (2011) on a study on access to credit noted that those who accessed financial institutions for investment from formal financial services were only 6.24\%. Attanasio, Augsburg, de Haas, Fitzsimons and Harmgart (2011) who found about half of all microcredit business loans in Mongolia are used for purposes associated with the household, such as the purchase of domestic appliances. Beck (2012) also noted that not all that was borrowed that ended to income generating activities. Actually, majority of the respondents who were undertaking investment indicated that the main source of capital was own savings. Similar findings were by Musau and Gakuu (2013) who also noted that, the main source of funds for investment among the youth was personal savings. Failure to understand the potential of credit facilities has seen the youth churn away from credit facilities.

World Bank (2014) noted lack of financial capability leads to poor decision making. Consumers are ignorant of the features of various financial products that they leave the financial institutions to exploit them. (World Bank, 2014). World Bank (2014) further noted that financial literacy leads to inefficient consumer credit market outcomes and over-indebtedness. This has made the poor to shy away from financial institutions for credit. Other studies that have indicated poor decision making in usage of financial products included Gross and Souleles (2002) and Massoud, Saunders, and Scholnick (2007).

Agarwal et al., (2009), from a study of about 128,000 credit card holders found that 28 percent make mistakes and they pay extra penalties. Ellis et al., (2009) noted lack of financial capability was impending the usage of financial services by Kenyans towards usage of financial products. CYFI (2012) indicated that with increased financial literacy, there is increased financial management and usage of financial products, which leads to increased investment and improved economic growth.

Lusardi and Mitchell $(2006 ; 2007)$ show that those who display low financial literacy are less likely to plan for retirement and as a result accumulate much less wealth. Thus, individuals are not able to take advantage of financial inclusion when financial capability is low. Financial service providers exploit the low level of financial capability and sometimes individuals pay higher interest rates than they should.

\section{Conclusion and recommendation:-}

This study noted that the youth were highly financially included in terms of access to financial services. The study also noted that financial capability among the youth was low. On the other hand, usage of financial services for investment purposes was noted to be low as the usage of financial services in terms of borrowing and insurance was very low. In that case, this study concludes that, though there has been increase in financial inclusion, it is not coupled with increase in investment. The study has also noted that, financial capability was statistically related to investment. In that case, low financial capability has effect on investment among the youth and thus the reason of low investment despite high levels of financial inclusion.. As a way of enhancing investment and ensuring financial inclusion achieves its objective, this study recommends enhancement of financial capability among the youth. This will enhance the utilization of financial services among the youth towards investments.

\section{Reference:-}

1. Agarwal, S., Driscoll, J., Gabaix, X. \& Laibson, D. (2009): The age of reason: Financial decisions over the lifecycle with implications for regulation. Brookings Papers on Economic Activity, Fall, 51-101.

2. Alliance for Financial Inclusion (2014): Putting Financial Inclusion on the Global Map: The 2013 Maya Declaration Progress Report. Wattana, Bangkok, Thailand

3. Ashraf, N., Karlan, D. \& Yin, W. (2010): Female empowerment: Impact of a commitment savings product in the Philippines. World Development, 38 (3), 333-44

4. Atkinson, A. (2007): Financial capability amongst adults with literacy and numeracy needs. Basic Skills Agency.

5. Attanasio, O., Augsburg, B., de Haas, R., Fitzsimons, E. \& Harmgart, H. (2011): Group lending or individual lending? evidence from a randomised field experiment in Mongolia. Working Paper W11/20. London: Institute for Fiscal Studies 
6. Augsburg, B., de Haas, R., Harmgart, H. \& Meghir, C. (2012): Microfinance at the margin: experimental evidence from Bosnia and Herzegovina. Working Paper 146. London: European Bank for Reconstruction and Development.

7. Balwanz, D. (2012): Youth Skills development, informal employment and the enabling environment in Kenya: Trends and tensions. Journal of International Cooperation in Education, 15 (2), 69 - 91

8. Banerjee, A. V., and Newman, A. F. (1993): Occupational Choice and the Process of Development. Journal of Political Economy, 101 (2), 274-298.

9. Central Bank of Kenya. (2014): Weekly Statistical Bulletin of Key Monetary and Financial Indicator, December 2014 edition

10. Central Bank of Kenya. (2015): Weekly Statistical Bulletin of Key Monetary and Financial Indicator, February 2015 edition

11. Cole, S., Sampson, T., and Zia, B. (2011): Prices or Knowledge? What Drives Demand for Financial Services in Emerging Markets. Journal of Finance 66 (6), 1933-1967.

12. Cull, R., Tilman, E. and Nina, H (2014): Financial inclusion and development: Recent impact evidence. Focus Note 92. Washington, D.C.: CGAP.

13. Demirguc-Kunt, A., Klapper, L., Singer, D., and Oudheusden, P. V (2015): The Global Findex Database 2014: Measuring Financial Inclusion around the World. Policy Research Working Paper 7255, World Bank, Washington, DC.

14. Ellis, K., Lemma, A., and Rud, J. (2010): Investigating the impact of access to financial services on household investment. Overseas Development Institute, Westminster Bridge Road, London

15. Evans, D. S., and Jovanovic, B. (1989): An Estimated Model of Entrepreneurial Choice under Liquidity Constraints. Journal of Political Economy, 97 (4), 808-827

16. FinAccess, (2013): National Survey. Profiling developments in financial access and usage in Kenya. Central Bank of Kenya and Financial Sector Deepening publication

17. FinAccess, (2016): National Survey. Profiling developments in financial access and usage in Kenya. Central Bank of Kenya and Financial Sector Deepening publication

18. Galor, O., and Zeira, P. (1993): Income Distribution and Macroeconomics. Review of Economic Studies 60 (1), $35-52$.

19. Githui, T., and Ngare, P. (2014): Financial Literacy and Retirement Planning in the Informal Sector in Kenya. International Journal of Education and Research 2 (1)1-16

20. Hannig, A., and Jansen, S. (2010): Financial inclusion and financial stability: Current policy issues. ADBI Working Paper 259. Tokyo: Asian Development Bank Institute.

21. Ibrahim, M. E., \& Alqaydi R. F. (2013): Financial literacy, personal financial attitude, and forms of personal debt among residents of the UAE. International Journal of Economics and Finance, 5(7), 126-142

22. Kalunda, E. (2014): Financial inclusion impact on small-scale tea farmers in Nyeri County. World Journal of Social Sciences, 4(1), 130 - 139

23. Kenya Bureau of Statistics (2014): Economic Survey Report, 2014

24. Loury, G. (1981): Intergenerational transfers and the distribution of earnings. Econometrica 49, 843-867.

25. Lusardi, A., \& Mitchell, O. S. (2011): Financial literacy and retirement planning in the United States. Journal of Pension Economics and Finance

26. Mastroyiannis, A. (2007): Current account dynamics and the feldstein and horioka puzzle: The case of Greece. The European Journal of Comparative Economics. 4(1), 91-99

27. Mbarire, T. T. and Ali, A. I (2014): Determinants of financial literacy levels among employees of Kenya Ports Authority in Kenya. Research Journal of Finance and Accounting, 5 (16), 44-52

28. Mutia, M. T. (2014): Study on mainstreaming equity and poverty in reduction in policies strategies and programmes in Kenya (With Special focus on Youth and Women). United Nations Development Programme

29. Mwangi, I. W., \& Sichei, M. M. (2011): Determinants of access to credit by individuals in Kenya: A comparative analysis of the Kenya National FinAccess Surveys of 2006 and 2009. European Journal of Business and Management, 3(3), 206-227

30. Mwangi, I. W., and Sichei, M. M. (2011): Determinants of Access to Credit by Individuals in Kenya: A Comparative Analysis of the Kenya National FinAccess Surveys of 2006 and 2009. European Journal of Business and Management, 3(3), 206-227

31. Narayan, P. K. (2005): The relationship between saving and investment for Japan. Japan and the world economy, 17(3), 293-309

32. Ndii, D. (2009): Financial inclusion: Recent developments and lessons from Kenya. Financial Inclusion in Kenya. 
33. Piketty, T. (1997): Theories of Persistent Inequality and Intergenerational Mobility, in Handbook of Income Distribution, Volume 1. Edited by A. B. Atkinson and F Bourguignon, Elsevier Science B. V.

34. Republic of Kenya (2013a): Second Medium Term Plan, 2013 - 2017

35. Republic of Kenya (2013b): Millennium Development Goals, Status Report for Kenya 2013

36. Republic of Kenya (2014): Youth employment in Africa: Policies, mechanisms and schemes for integration of youth into the workforce and job creation, Kenya country report. Nairobi: Government printer

37. United Nations Development Programme (2013): Financial inclusion of youth.

38. United Nations, (2006): Building Inclusive Financial Sectors for Development. New York

39. Villasenor, J. D., West, D. M. and Lewis, R. J. (2015): The 2015 Brookings financial and digital inclusion project report: Measuring Progress on Financial Access and Usage. Center for Technology Innovation (CTI) at Brookings, Washington, DC, 1-188

40. World Bank (2008): Finance for All? Policies and Pitfalls in Expanding Access. Washington DC

41. World Bank (2014): Global Financial Development Report 2014: Financial Inclusion. Washington, DC: World Bank. doi:10.1596/978-0-8213-9985-9. 